mgr Kamil Krzyżanowskia)*, dr n. o zdr. Daniel Ślęzak ${ }^{a}$, podinsp. dr Paweł Jastrzębskib), mgr Przemysław Żuratyńskia), Paulina Bucaa), inż. Bartłomiej Ślęczkowskic)

\author{
a) Gdański Uniwersytet Medyczny / Medical University of Gdańsk \\ ${ }^{b)}$ Wyższa Szkoła Policji w Szczytnie / Police Academy in Szczytno \\ c) Centrum Naukowo-Badawcze Ochrony Przeciwpożarowej - Państwowy Instytut Badawczy / Scientific and Reserach Centre for Fire \\ Protection - National Research Institute \\ *Autor korespondencyjny / Corresponding author: kamkrz@gumed.edu.pl
}

\title{
Przyrządowe techniki udrożniania dróg oddechowych - nowe uprawnienia ratowników medycznych straży pożarnych
}

\author{
Airway Management with the Use of Instruments - New Competences \\ for Fire Service Paramedics
Восстановление проходимости дыхательных путей с помощью приборов - новые полномочия медработников пожарной службы

\begin{abstract}
ABSTRAKT
Cel: Celem pracy jest omówienie przyrządowych technik udrożniania dróg oddechowych, służących zwiększeniu efektywności wentylacji u poszkodowanych, które zgodnie z nowelizacją ustawy o Państwowym Ratownictwie Medycznym mogą być wykorzystywane przez ratowników medycznych pełniących służbę w Państwowej Straży Pożarnej oraz działających w ramach Ochotniczych Straży Pożarnych.

Wprowadzenie: Nowelizacja ustawy z dnia 25 września 2015 r. o Państwowym Ratownictwie Medycznym (PRM) i rozporządzenie Ministra Zdrowia z dnia 20 kwietnia 2016 r. w sprawie medycznych czynności ratunkowych i świadczeń zdrowotnych innych niż medyczne czynności ratunkowe, które mogą być udzielane przez ratownika medycznego, znacznie rozszerzają zakres działania ratowników oraz kompetencje osób pracujących w systemie PRM i jednostkach wspomagających ten system (Państwowej Straży Pożarnej, policji, Tatrzańskim, Górskim i Wodnym Ochotniczym Pogotowiu Ratunkowym oraz innych organizacjach i stowarzyszeniach, które w ramach swojej działalności statutowej wykonują zadania ratownicze). Przed wejściem w życie nowelizacji ustawy, ratownicy i ratownicy medyczni pełniący służbę w jednostkach Państwowej Straży Pożarnej wykonywali procedury zgodne z ramowym programem kursu w ramach kwalifikowanej pierwszej pomocy (KPP). Po nowelizacji ustawy [1] ratownicy medyczni pełniący służbę w PSP nie sa już ograniczani wyłącznie do zakresu KPP. Zgodnie z nabytą wiedzą i umiejętnościami mogą podejmować medyczne czynności ratunkowe. Autorzy omówili techniki przyrządowego udrożniania dróg oddechowych, które w obecnym brzmieniu ustawy mogą być wykorzystywane przez ratowników medycznych - poczynając od najprostszych rurek ustno-gardłowych (dostępnych przed nowelizacją Ustawy dla ratowników działających w ramach KPP), a kończąc na niedostępnej przed zmianą przepisów (w ramach działań straży pożarnej) intubacji dotchawiczej.

Wnioski: Zastosowanie właściwych i dostosowanych do stanu pacjenta technik udrożniania górnych dróg oddechowych, w szczególności przyrządowych, może znacznie poprawić jakość prowadzonej wentylacji. Prawidłowy przepływ powietrza (tlenu) przez drogi oddechowe jest jednym z elementów warunkujących optymalne funkcjonowanie wszystkich układów i narządów. Metody zaawansowane nie mogły być do tej pory stosowane przez ratowników medycznych w ramach służby w PSP, co mogło ograniczać skuteczność prowadzonych przez nich czynności.

Znaczenie dla praktyki: W artykule autorzy zwracają uwagę jedynie na zaawansowane techniki ułatwiające utrzymanie drożności dróg oddechowych, które powinny zastępować powszechnie znane i często omawiane techniki bezprzyrządowe.

Słowa kluczowe: niedrożność dróg oddechowych, udrożnianie dróg oddechowych, intubacja dotchawicza, techniki nadgłośniowe, Państwowe Ratownictwo Medyczne, Państwowa Straż Pożarna, Ochotnicza Straż Pożarna

Typ artykułu: artykuł przeglądowy
\end{abstract}

Przyjęty: 14.03.2017; Zrecenzowany: 07.07.2017; Opublikowany: 30.09.2017;

Procentowy wkład merytoryczny w opracowanie artykułu: K. Krzyżanowski - 20\%, P. Buca - 20\%, D. Ślęzak - 15\%, P. Jastrzębski - 15\%,

P. Żuratyński - 15\%, B. Ślęczkowski - 15\%;

Proszę cytować: BiTP Vol. 47 Issue 3, 2017, pp. 112-123, doi: 10.12845/bitp.47.3.2017.9;

Artykuł udostępniany na licencji CC BY-NC-SA 4.0 (https://creativecommons.org/licenses/by-nc-sa/4.0/). 


\section{ABSTRACT}

Aim: The aim is to discuss airway management with the use of instruments to increase the efficiency of patient ventilation which, according to the amendment of the Act on State Emergency Medical Services (PRM), can be applied by paramedics serving in the State Fire Service and the Volunteer Fire Service. Introduction: The amendment to the Act on PRM of 25 September 2015, and the Regulation of the Minister of Health of 20 April 2016 on medical treatment and health services other than medical rescue activities which can be provided by a paramedic considerably extend the competences of people working in the PRM system as well as in units supporting the system (the State Fire Service, the Police, and the Tatra Mountains, Mountains and Water Volunteer Rescue Service, and also other organisations and associations which perform rescue operations as part of their statutory activities). Before the coming into force of the amendment to the Act, rescuers and paramedics on duty in units of the State Fire Service performed procedures in accordance with the framework programme of the course within qualified first aid (QFA). After the amendment of the Act [1] paramedics are no longer limited only to the QFA, and may perform medical rescue activities based on their acquired knowledge and skills. The authors discuss airway management techniques with the use of instruments, which pursuant to the current version of the Act can be used by paramedics, starting from the simplest - oropharyngeal tubes (before the amendment of the Act available to paramedics operating on the basis of QFA), ending with those which were inaccessible before the change in regulations (within State Fire Service operations), namely tracheal intubation.

Conclusion: Using the proper upper airway management techniques adjusted to the patient's condition, especially with the use of instruments, can significantly improve the quality of ventilation. The normal flow of air / oxygen through airways is one of the elements contributing to the optimal functioning of all organs and systems.

Practical significance: In this article, the authors focus on the advanced techniques facilitating airway management, which should replace the well-known and often discussed techniques without the use of instruments.

Keywords: airway obstruction, airway management, tracheal intubation, supraglottic techniques, State Emergency Medical Services, State Fire Service Type of article: review article

Received: 14.03.2017; Reviewed: 07.07.2017; Published: 30.09.2017;

Percentage contribution: K. Krzyżanowski - 20\%, P. Buca - 20\%, D. Ślęzak -15\%, P. Jastrzębski - 15\%, P. Żuratyński - 15\%, B. Ślęczkowski;

Please cite as: BiTP Vol. 47 Issue 3, 2017, pp. 112-123, doi: 10.12845/bitp.47.3.2017.9;

This is an open access article under the CC BY-NC-SA 4.0 license (https://creativecommons.org/licenses/by-nc-sa/4.0/).

\section{АННОТАЦИЯ}

Цель: Целью данной работы является рассмотрение методов восстановления проходимости дыхательных путей, направленных на повышение эффективности вентиляции у пострадавших, которые, в соответствии с поправкой к закону о государственной скорой медицинской помощи, могут быть использованы медработниками, находящимися на службе в Государственной Пожарной Службе и работающими в добровольных пожарных дружинах.

Введение: Поправка к закону от 25 сентября 2015 года о Государственной Скорой Медицинской Помощи (РRM) и распоряжение Министра здравоохранения от 20 апреля 2016 года относительно медицинских действий неотложной медицинской помощи и других услуг здравоохранения, не относящихся к ним, которые могут выполнять медработники, значительно расширяют спектр полномочий тех, кто работает в системе PRM и подразделениях, поддерживающих эту систему (Государственной Пожарной Службе, полиции, Татранской, Горной и Водяной Добровольных Спасательных Службах, а также других организациях и союзах, которые в рамках своей уставной деятельности выполняют аварийно-спасательные действия). До вступления в силу поправки к закону спасатели и медработники, служащие в подразделениях Государственной Пожарной Службы, осуществляли процедуры в соответствии с установленной программой обучения в рамках квалифицированной первой помощи (КРP). После внесения поправок в Закон [1] медработники, работающие в ГПС, больше не ограничены только КРР. Согласно полученным знаниям и умениям они могут проводить медицинские спасательные действия. Авторы обсуждают методы восстановления проходимости дыхательных путей при помощи специального оборудования, которое в настоящим толковании закона может быть использовано медработниками - начиная от простых ротовых трубок (доступных до изменения закона для спасателей, действующих в рамках КРР) и заканчивая на недоступной перед изменением законов (в пределах действий ГпС) эндотрахеальной интубации. Выводы: Использование соответствующих методов восстановления проходимости верхних дыхательных путей, учитывающих также состояние пациента, в частности с участием приборов, может значительно повысить качество проводимой вентиляции. Правильный поток воздуха (кислорода) через дыхательные пути является одним из условий, необходимых для оптимального функционирования всех систем и органов. Усовершенствованные методы не могли быть до сих пор использованы спасателями, работающими в ГпС. Это ограничение могло снижать эффективность проводимых ими мероприятий.

Значение для практики: В этой статье авторы указывают только на сложные методы, которые помогают поддерживать проходимость дыхательных путей и должны заменять широко известные и часто рассматриваемые методы, при которых не используются специализированные приборы.

Ключевые слова: непроходимость дыхательных путей, очистка дыхательных путей, эндотрахеальная интубация, государственная скорая медицинская помощь, Государственная пожарная служба, Добровольная пожарная служба

Вид статьи: обзорная статья

Принята: 14.03.2017; Рецензирована: 07.07.2017; Опубликована: 30.09.2017;

Процентное соотношение вклада в создание статьи: K. Krzyżanowski - 20\%, P. Buca - 20\%, D. Ślęzak - 15\%, P. Jastrzębski - 15\%,

P. Żuratyński - 15\%, B. Ślęczkowski - 15\%;

Просим ссылаться на статью следующим образом: BiTP Vol. 47 Issue 3, 2017, pp. 112-123, doi: 10.12845/bitp.47.3.2017.9:

Настоящая статья находится в открытом доступе и распространяется в соответствии с лицензией CC BY-NC-SA 4.0 (https://creativecommons.org/ licenses/by-nc-sa/4.0/). 


\section{Stan prawny po nowelizacji ustawy o Państwowym Ratownictwie Medycznym z 25 września 2015 r.}

Nowelizacja ustawy o Państwowym Ratownictwie Medycznym z 25 września 2015 r. wnosi zapisy precyzujące, gdzie ratownik medyczny może wykonywać zadania zawodowe (w tym medyczne czynności ratunkowe). W art. 11. ust. 3. pkt 7. tej ustawy określono, że miejscem tym mogą być jednostki ochrony przeciwpożarowej, o których mowa w art. 15 ustawy z dnia 24 sierpnia 1991 r. o ochronie przeciwpożarowej.

Aktem wykonawczym do ww. ustawy jest rozporządzenie Ministra Zdrowia z dnia 20 kwietnia 2016 r. w sprawie medycznych czynności ratunkowych i świadczeń zdrowotnych innych niż medyczne czynności ratunkowe, które mogą być udzielane przez ratownika medycznego. Przywołane rozporządzenie określa, jakie medyczne czynności ratunkowe może wykonywać ratownik medyczny samodzielnie lub na zlecenie lekarza. Zaliczają się do nich m.in. przyrządowe i bezprzyrządowe techniki udrożniania dróg oddechowych.

Przed zmianami w przepisach ratownicy medyczni pełniący służbę w Państwowej Straży Pożarnej mogli podejmować jedynie czynności określone w postępowaniu na poziomie kwalifikowanej pierwszej pomocy (KPP). Obecnie zakres ich działań został znacznie rozszerzony, m.in. o przyrządowe techniki udrożniania dróg oddechowych. W związku z powyższym autorzy zdecydowali się omówić ten temat w niniejszej pracy.

\section{Zarys anatomii układu oddechowego}

Podstawowym zadaniem układu oddechowego jest prowadzenie wymiany gazowej. W fazie wdechu tlen dociera do pęcherzyków płucnych, gdzie przenika do krwi i jest z nią transportowany do całego ustroju. Równocześnie z krwi do pęcherzyków płucnych przenika dwutlenek węgla, który jest usuwany z organizmu podczas wydechu.

Drogi oddechowe można podzielić na dwa odcinki: dolny i górny. Poczynając od góry, powietrze pokonuje kolejno jamę nosową, gardło, krtań (która jest uważana za granicę dolnych i górnych dróg oddechowych), tchawicę, oskrzela i oskrzeliki, a na końcu dociera do pęcherzyków płucnych.

\section{Jama ustna}

Jama ustna stanowi początek dwóch układów: pokarmowego i oddechowego. Ograniczają ją wargi i policzki, od wewnątrz podniebienie twarde i miękkie, a w tylnej części tzw. języczek. Dno jamy ustnej tworzą mięśnie nadgnykowe i żuchwowo-gnykowe. Narządy ulokowane w jamie ustnej to ślinianki, zęby i język. Ten ostatni jest dość istotny z uwagi na poruszany problem drożności dróg oddechowych. Przy zwartych szczękach wypełnia on niemalże całkowicie jamę ustną. Jego mięśnie łączą się z żuchwą i poprzez więzadła z kością gnykową. W sytuacji utraty świadomości i ułożeniu ciała na plecach znaczna masa języka sprawia, że opadając zgodnie z siłą grawitacji, blokuje on drogi oddechowe. Przeszkodami w jamie ustnej, które mogą utrudniać wstępne prowadzenie skutecznej wentylacji za pomocą worka samorozprężalnego, w chwili kiedy dojdzie do nagłego zatrzymania krążenia (NZK), są także:

- nadmierna produkcja śliny - np. stan po napadzie drgawek, zatrucie fosforoorganicznymi środkami ochrony roślin;

- protezy zębowe, koronki, mostki - mechaniczna blokada dróg oddechowych.

\section{Jama nosowa}

Do jamy nosowej powietrze dostaje się przez nozdrza przednie i przedsionek nosa. Podzielona jest ona przez przegrodę nosową na dwie części. W bocznej części znajdują się ujścia zatok przynosowych, których zadaniem jest utrzymanie normotermii w obszarze podstawy czaszki i wzmacnianie głosu poprzez rezonans. W części tylnej jama nosowa połączona jest z częścią nosową jamy gardła.

\section{Gardło}

Jest to kolejna część górnych dróg oddechowych. Zajmuje przestrzeń pomiędzy podstawą czaszki a wysokością VI kręgu szyjnego. Za dolną krawędź uznaje się wysokość kości gnykowej. Gardło stanowi wspólny odcinek przewodu pokarmowego i układu oddechowego, co sprzyja powstawaniu niedrożności dróg oddechowych.

\section{Krtań}

Narząd łączący gardło z tchawicą. Uznawany jest za granicę dolnych i górnych dróg oddechowych. Zlokalizowana na wysokości IV-VII kręgu szyjnego, poniżej kości gnykowej i nasady języka. Kość gnykowa jest podstawą dla szkieletu chrzęstnego krtani składającego się z elementów parzystych (chrząstki nalewkowate, klinowate i różkowate) oraz nieparzystych (nadgłośniowa, pierścieniowata i tarczowata). Z punktu widzenia zadanego tematu istotnym elementem $\mathrm{w}$ budowie krtani jest błona pierścienno-tarczowa znajdująca się pomiędzy chrząstkami o tych samych nazwach. Stanowi ona bardzo dobre miejsce do uzyskania dostępu do dróg oddechowych z wykorzystaniem metod chirurgicznych (konikotomia, konikopunkcja). Innym ważnym punktem jest nagłośnia. Łączy się z wewnętrzną częścią chrząstki tarczowatej oraz z kością gnykową i żuchwą. Uważa się, że to właśnie ta struktura, u osób nieprzytomnych, odpowiada za niedrożność dróg oddechowych. W wyniku rozluźnienia mięśni i przygięcia głowy do klatki piersiowej, nagłośnia opada na wejście do głośni całkowicie ją zamykając.

\section{Tchawica}

U osób dorosłych jest to około 12-centymetrowy przewód łączący krtań z oskrzelami. Zlokalizowana jest pomiędzy VII kręgiem szyjnym a $V$ piersiowym, przechodząc w oskrzele. Zbudowana jest z 16-20 chrząstek o podkowiastym kształcie. Przestrzeń bez pokrycia chrzęstnego tworzy gładka błona mięśniowa, daje to stabilność i elastyczność narządu oraz optymalny przepływ powietrza. 


\section{Oskrzela}

Rozejście oskrzeli głównych prawego i lewego szacuje się na kąt $85^{\circ}$. Różnią się one budową. Część prawa stanowi przedłużenie wyżej zlokalizowanej tchawicy $\mathrm{i}$ - w odróżnieniu od oskrzela lewego - przebiega bardziej pionowo, jest szersza i krótsza. Oskrzele lewe ma mniejszą średnicę. Jest dłuższe i położone bardziej poziomo. Omówiona budowa ma znaczenie pod kątem prawdopodobieństwa penetracji ciała obcego. W większości przypadków lokalizuje się je w oskrzelu prawym. Budowa anatomiczna oskrzeli głównych oraz niewłaściwe umieszczenie rurki intubacyjnej (umieszczenie jej zbyt głęboko) mogą prowadzić do zaintubowania jedynie oskrzela głównego prawego.

\section{Przyrządowe techniki udrażniania dróg oddechowych}

Przyrządy umożliwiające udrożnienie dróg oddechowych na poziomie zaawansowanym można podzielić na nadkrtaniowe i podgłośniowe:
1) rurka ustno-gardłowa;

2) rurka nosowo-gardłowa;

3) maska krtaniowa (classic, pro seal, supreme);

4) maska krtaniowa I-GEL;

5) rurka krtaniowa;

6) rurka dwuświatłowa Combitube;

7) rurka intubacyjna;

8) zestaw do konikopunkcji.

\section{Rurka ustno-gardłowa}

Jednym z elementów pierwotnie blokujących drogi oddechowe może być opadający na tylną ścianę gardła język. W opisie wszelkich technik przyrządowych udrożniana górnych dróg oddechowych znajdujemy zapisy, iż każda interwencja tego typu powinna być poprzedzona manewrami bezprzyrządowymi, takimi jak rękoczyn czoło-żuchwa czy wysunięcie żuchwy. Pierwszym i najprostszym urządzeniem utrzymującym drożność dróg oddechowych jest, opracowana w latach 30 . ubiegłego wieku przez Artura Guedela, rurka ustno-gardłowa.

Rycina 1. Rurka ustno-gardłowa

Figure 1. Oropharyngeal tube

Źródło: Opracowanie własne.

Source: Own elaboration.

Kształt i budowa rurki UG zapobiegają przemieszczaniu się języka ku tylnej ścianie gardła i podniebieniu miękkiemu. Rurka ułatwia tym samym swobodny ruch powietrza pomiędzy ustami a pęcherzykami płucnymi osoby poszkodowanej. Strażakom-ratownikom oraz członkom zespołu ratownictwa medycznego ułatwia nie tylko prowadzenie wentylacji zastępczej, ale również odsysanie zalegającej wydzieliny. Aby rurka prawidłowo spełniała swoje funkcje, jej rozmiar powinien być dopasowany do osoby ratowanej. Producent rurek zaleca dwie techniki doboru wielkości:

1. Długość rurki powinna odpowiadać odległości pomiędzy kątem żuchwy a siekaczami bądź miejscem, gdzie znajdowałyby się one u poszkodowanego;

2. Długość rurki powinna odpowiadać odległości od płatka ucha do kącika ust osoby ratowanej.

Założenie rurki jest poprzedzane udrożnieniem dróg oddechowych metodami bezprzyrządowymi. Rurkę początkowo wkłada się do jamy ustnej poszkodowanego w sposób odwrotny do jej końcowego położenia (zadarty w górę koniec prowadzi się po podniebieniu). Po osiągnięciu pierwszego oporu rurkę należy obrócić o 180 stopni, uzyskując prawidłowe ułożenie. Technika ta pozwala ominąć wiotki szczyt języka i wprowadzić rurkę bez oporu w dolną część jamy ustnej i gardła. Rzadziej spotykaną techniką jest wprowadzanie rurki UG z zastosowaniem szpatułki, za pomocą której unoszony jest język. Rurka wprowadzana jest wtedy bez wykonywania rotacji. Technika ta jest stosowana u dzieci.

Użycie rurki UG dozwolone jest wyłącznie u osób głęboko nieprzytomnych. Możliwym działaniem ubocznym są wymioty (wywołane odruchem z tylnej ściany gardła). Mogą one stwarzać ryzyko aspiracji treści żołądkowej do dróg oddechowych. W przypadku wystąpienia odruchu wymiotnego należy natychmiast usunąć rurkę z jamy ustnej. Rurki UG nie można połączyć w żaden sposób z workiem samorozprężalnym, dlatego konieczna jest ciągła dbałość o prawidłowe uszczelnienie maski na twarzy poszkodowanego. Rurka ustno-gardłowa znajduje się na wyposażeniu zestawów PSP R1. 


\section{Rurka nosowo-gardłowa}

Jest to przyrząd wynaleziony z końcem lat 50. przez Johanna Wendla. W odróżnieniu od rurki ustno-gardłowej, rurka nosowo-gardłowa może być użyta u osób płytko nieprzytomnych. Zalecana jest przede wszystkim u świeżorodków, noworodków i niemowląt. Jest lepiej tolerowana i nie powoduje silnych odruchów wymiotnych. W przypadku zauważenia objawów odruchu wymiotnego, rurkę należy niezwłocznie usunąć i przygotować się do odessania treści żołądkowej. Niestety podobnie jak rurka Guedela nie posiada ona elementów zabezpieczających przed zachłyśnięciem. Rurki nosowo-gardłowe występują w rozmiarach: 2-8 mm średnicy i 95-170 mm długości.

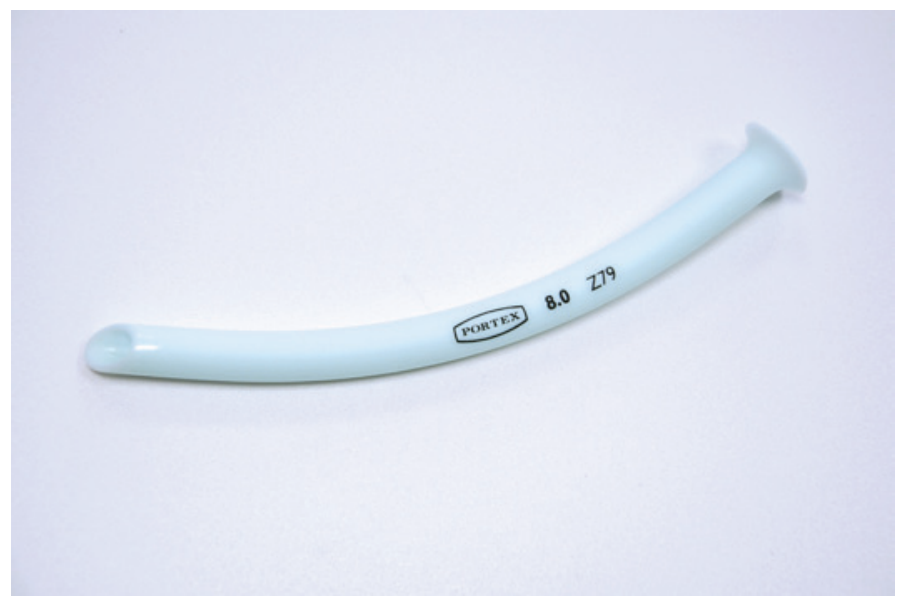

Rycina 2. Rurka nosowo-gardłowa

Figure 2. Nasopharyngeal tube

Źródło: Opracowanie własne.

Source: Own elaboration.

Dobór rozmiaru rurki opiera się na dopasowaniu jej do średnicy małego palca lub odległości pomiędzy końcem nosa a płatkiem ucha poszkodowanego. Do założenia rurki warto użyć lubrykantu. Rurkę wprowadza się do prawego nozdrza. Ścięty koniec powinien być skierowany do przegrody. Następnie przy jednoczesnym wykonywaniu naprzemiennych ruchów rotacyjnych należy delikatnie wprowadzać rurkę w głąb. Urządzenie zakończone jest kryzą, uniemożliwiającą wprowadzenie przyrządu zbyt głęboko. Każdy opór podczas zakładania powinien skutkować natychmiastowym jego usunięciem. Rurki nosowo-gardłowe znajdują zastosowanie u osób z obrażeniami twarzoczaszki. Bezwzględnym przeciwskazaniem do ich użycia są obrażenia czaszkowo-mózgowe, gdyż przy uszkodzeniu blaszki sitowej istnieje ryzyko wprowadzenia rurki do jamy czaszki. Najczęstszym jednak powikłaniem wprowadzenia rurki jest krwawienie z nosa, występujące nawet u $30 \%$ poszkodowanych. Również w tej sytuacji należy mieć przygotowany ssak.

\section{Maska krtaniowa}

Twórcą masek krtaniowych był Archibald Brain. Zamysłem stworzenia tego urządzenia było połączenie maski twarzowej z intubacją. Stosowanie masek pierwotnie miało być ograniczone do anestezjologii. Okazało się jednak, że przyrządy te mogą być stosowane z powodzeniem na etapie przedszpitalnym.

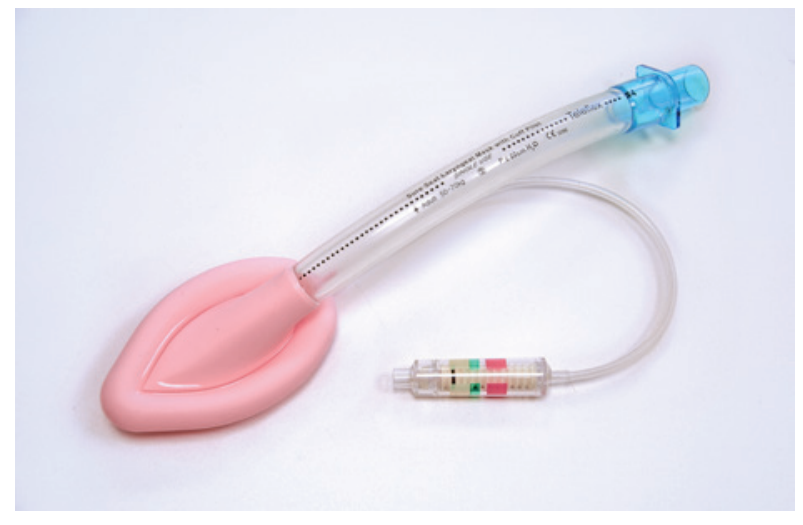

Rycina 3. Maska krtaniowa

Figure 3. Laryngeal mask

Źródło: Opracowanie własne.

Source: Own elaboration. 
Maska krtaniowa stała się pierwszą alternatywą dla intubacji. Powinna być stosowana u poszkodowanych głęboko nieprzytomnych. Jej zasada działania polega na objęciu wejścia do krtani elastycznym mankietem uszczelniającym (napełnianym powietrzem po umieszczeniu) i za pomocą połączonej do mankietu rurki "wydobyciu” dróg oddechowych powyżej poziomu ust. Daje to możliwość podłączenia bezpośrednio do urządzenia worka samorozprężalnego i prowadzenia skuteczniejszej wentylacji niż w przypadku rurki ustno-gardłowej czy nosowo-gardłowej. Przy prawidłowym założeniu (należy zaznaczyć, że dość łatwym, gdyż niewymagającym użycia laryngoskopu czy innego dodatkowego sprzętu) zapewnia ona zadowalającą szczelność. Jak każda z metod nadkrtaniowych nie w pełni zabezpiecza przed aspiracją treści żołądkowej. W celu dopasowania rozmiaru maski do poszkodowanego należy w przybliżeniu określić wagę pacjenta. Numeracja rozmiarów, w zależności od masy poszkodowanego, waha się od 1 dla osób o masie ciała $6,5 \mathrm{~kg}$, do 5 dla osób ważących powyżej $90 \mathrm{~kg}$. Przed wprowadzeniem maski można rozważyć użycie lubrykantu, jednak można nałożyć go jedynie na zewnętrzną część rurki bez nawilżania samego mankietu w części przylegającej do krtani. Maskę wprowadza się, stojąc za głową pacjenta i używając najdłuższego palca jako prowadnicy lub trzymając rurkę podobnie jak długopis. Opór podczas wprowadzania świadczy o dotarciu mankietu w docelowe położenie (oparcie o górny zwieracz przełyku). Nie należy wtedy dalej dociskać rurki. Następnie należy uzupełnić mankiet powietrzem zgodnie z zaleceniami producenta. Co ważne, rurka po założeniu musi zostać umocowana centralnie w osi ciała, ponieważ w przypadku przesunięcia jej trzonu do kącika ust, może wystąpić nieszczelność mankietu. Podczas wentylacji prowadzonej za pomocą maski krtaniowej nie należy przekraczać ciśnienia $20 \mathrm{~cm} \mathrm{H20,} \mathrm{gdyż} \mathrm{może} \mathrm{to} \mathrm{prowadzić} \mathrm{do} \mathrm{rozszczelnienia}$ układu i rozdęcia żołądka.

W 1988 roku wprowadzono pewną modyfikację maski klasycznej, projektując nowy układ uszczelniający (maska ProSeal). Mankiet w części przodującej jest cieńszy i wyprowadza port umożliwiający odessanie treści żołądkowej. Część tylna została rozbudowana w stosunku do pierwowzoru. Taka budowa znacznie zwiększyła stabilność i szczelność maski, dając komfort pracy nawet przy obciążeniu ciśnieniem 35 cm H20. Dodatkowym elementem jest wbudowane zabezpieczenie przed przygryzieniem. Za wadę należy uznać konieczność użycia dedykowanej prowadnicy w celu prawidłowego założenia maski. Podobnym urządzeniem jest maska Supreme.

Rycina 4. Maska krtaniowa (Supreme)

Figure 4. Laryngeal mask (Supreme)

Źródło: Opracowanie własne.

Source: Own elaboration.

W obecnej formie maska Supreme pozwala na wentylację ciśnieniami o wartościach $30-35 \mathrm{~cm} \mathrm{H20}$. W stosunku do masek klasycznych jest bardziej wygięta i lepiej dopasowana do anatomii dróg oddechowych. Dzięki owalnemu kształtowi rurka pozwala uzyskać lepszą stabilność w ustach poszkodowanego. W górnej części zbudowana jest z twardego tworzywa uniemożliwiającego przygryzienie. Sposób wprowadzenia i uszczelnienia maski Supreme jest taki sam jak w masce klasycznej.
I-GEL

Jest to jedno z najnowszych rozwiązań dostępnych na rynku sprzętu do zaawansowanego udrożniania dróg oddechowych. Pomimo braku mankietu pneumatycznego zapewnia on bardzo wysoką szczelność i pozwala wentylować poszkodowanego znacznie wyższymi ciśnieniami niż klasyczna maska krtaniowa. 


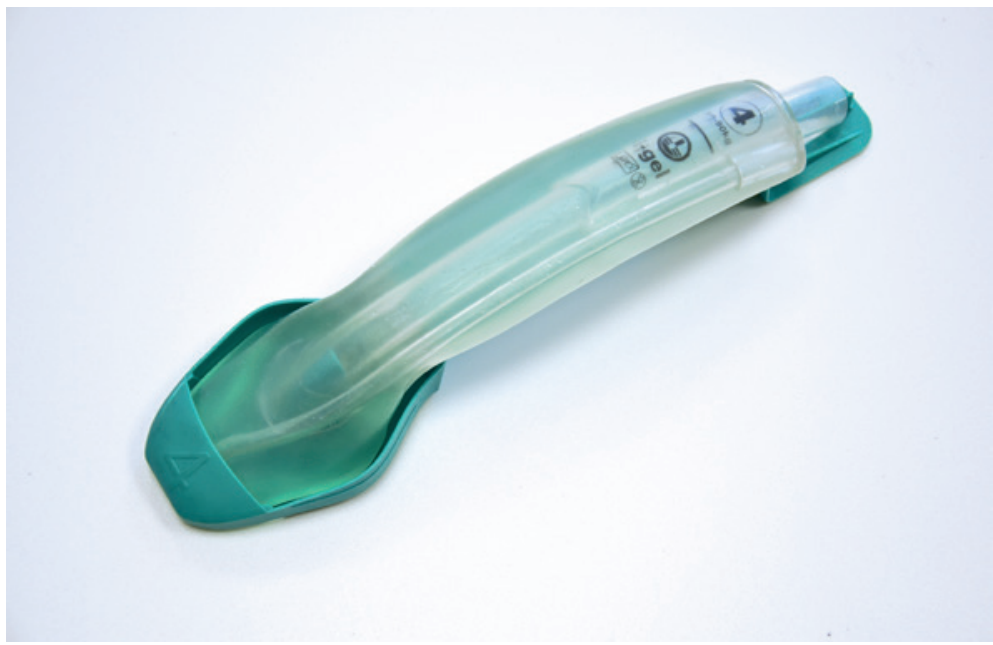

Rycina 5. I-GEL

Figure 5. I-GEL

Źródło: Opracowanie własne.

Source: Own elaboration.

Skuteczność tego urządzenia jest zapewniona dzięki termoplastycznej elastomerowej głowicy, która pod wpływem temperatury panującej $w$ drogach oddechowych dopasowuje się do struktur anatomicznych indywidualnych dla każdego poszkodowanego. Trzon maski jest zdecydowanie szerszy niż w innych modelach masek krtaniowych. Gwarantuje to znakomitą stabilizację w jamie ustnej. Podobnie jak w wariantach ProSeal i Supreme górna część trzonu zabezpieczona została przed przygryzieniem, a część przodująca głowicy wyposażona jest w wylot kanału umożliwiającego zgłębnikowanie żołądka. W opinii autorów jest to obecnie jeden z wiodących produktów na rynku, łączący w sobie bardzo wysoką jakość wentylacji, szybkość oraz prostotę założenia. Jedno z przeprowadzonych badań wykazało, iż w 82,5\% przypadków zastosowania tego przyrządu, czas założenia nie przekraczał 15 sekund. Maski typu I-GEL są wprowadzane do wyposażenia toreb R1.

\section{Rurka dwuświatłowa Combitube}

Rurki tego typu zostają powoli wypierane z wyposażenia ZRM i SOR. Ich wysoka cena, czasochłonna procedura założenia oraz bardzo sztywna część przodująca niejednokrotnie powodująca uszkodzenia błon śluzowych sprawiają, że potencjalni klienci szukają metod bardziej efektywnych. Jest to sprzęt, który wszedł na polski rynek ratowniczy w latach 90. Dziś dostępne są lepsze, bezpieczniejsze i szybsze sposoby na poprawę drożności dróg oddechowych.

Rycina 6. Rurka Combitube

Figure 6. Combitube

Źródło: Opracowanie własne.

Source: Own elaboration. 
Rurka Combitube należy do grupy urządzeń, do których zakładania niepotrzebne są prowadnice czy laryngoskop. Rurkę tę wprowadza się do dróg oddechowych „na ślepo”. Dzięki specyficznej budowie można ją wprowadzić zarówno do dróg oddechowych, jak i do przełyku. W obu wariantach możliwe jest podjęcie prawidłowej wentylacji. W przedniej części rurki znajdują się dwa niezależne mankiety uszczelniające. Po sprawdzeniu, czy rurka znajduje się we właściwej pozycji, należy uszczelnić odpowiedni mankiet. Najpoważniejszym błędem może być nierozpoznanie wprowadzenia rurki do przełyku i podjęcie wentylacji w tym kierunku. Potwierdzona badaniem skuteczność wentylacji z użyciem Combitube wynosi 79-98\%. Badaniem objęto przypadki wykorzystania tej metody w warunkach przedszpitalnych, czyli w warunkach pracy ratowników medycznych oraz funkcjonariuszy straży pożarnej, którzy często przybywają na miejsce zdarzenia jako pierwsi.

\section{Rurka krtaniowa (LT)}

Rurkę krtaniową można uznać za następcę rurki Combitube. Ideę wentylacji za pomocą przestrzeni pomiędzy dwoma mankietami uszczelniającymi znajdujemy po raz pierwszy właśnie w tym urządzeniu.

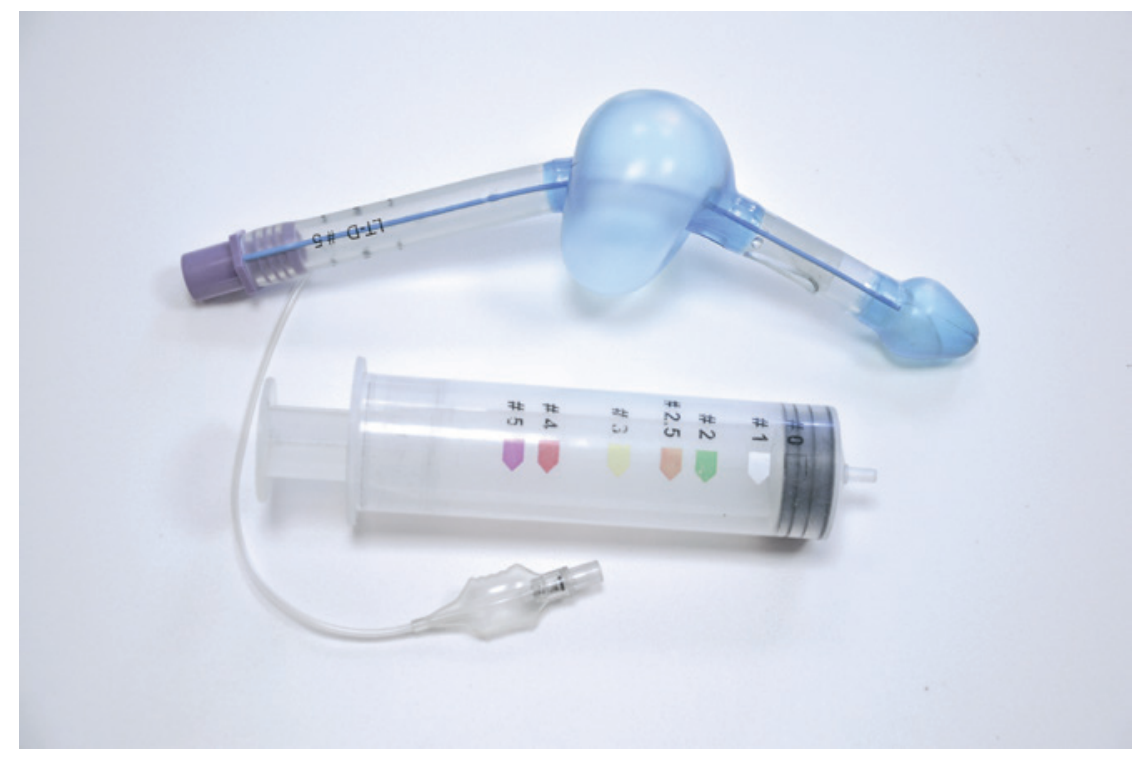

Rycina 7. Rurka krtaniowa (LT)

Figure 7. Laryngeal tube (LT)

Źródło: Opracowanie własne.

Source: Own elaboration.

Rurka LT z założenia wprowadzana jest zawsze do przełyku. Po osiągnięciu odpowiedniej głębokości (oznakowanej na trzonie rurki) należy uzupełnić powietrze w mankietach pneumatycznych i upewnić się, że wentylacja prowadzona jest skutecznie. Do uzupełnienia powietrza służy odpowiednio zakodowana oraz dołączona do zestawu strzykawka. llość powietrza, którą należy użyć określa kolor końcówki rurki oraz jej numer. Odpowiednio przygotowana strzykawka posiada oznaczenie zakodowane tym samym kolorem i cyfrą co oznaczenie na rurce. W odróżnieniu od swego pierwowzoru, w rurce LT oba mankiety pneumatyczne wypełniają się jednocześnie. Nie trzeba wybierać, który z nich należy uszczelnić. Dobór rozmiaru polega na ocenie wzrostu poszkodowanego (u osób dorosłych) i masy (u dzieci). Wszelkie informacje dotyczące numeracji rozmiaru określone są na opakowaniu. Podobnie jak w niektórych modelach masek krtaniowych w rurkach LT również można spotkać specjalnie przygotowane porty umożliwiające odsysanie treści żołądkowej. Oddziały lub jednostki, w których zakłada się częste wykorzystanie tego rodzaju urządzeń, mogą zakupić rurki wielokrotnego użycia, które można poddać 50-krotnej dekontaminacji w autoklawie. Najczęściej jednak w zespołach ratownictwa i jednostkach współpracujących z systemem i SOR użytkowane są rurki jednorazowe. Zgodnie z opinią środowisk medycznych, rurkę LT i maskę IGEL należy zaliczyć do najskuteczniejszych dostępnych obecnie metod nadkrtaniowych. Szacuje się, że 90\% przypadków stosowania rurek krtaniowych na etapie przedszpitalnym kończy się powodzeniem. Natomiast skuteczność wentylacji tym sposobem nieznacznie przekracza tę wartość.

\section{Intubacja dotchawicza}

Intubacja dotchawicza jest jak dotychczas najlepszą, najbardziej skuteczną, a co najważniejsze najbezpieczniejszą przyrządową metodą udrażniania dróg oddechowych. Jest jednak jedną z najtrudniejszych metod pozwalających prowadzić zaawansowaną wentylację zastępczą. Założeniem tej techniki jest wprowadzenie rurki do tchawicy przy uzyskaniu toru wizyjnego za pomocą laryngoskopu. Rurka wyposażona jest w swej dystalnej części w mankiet uszczelniający, co zabezpiecza poszkodowanego przed ewentualną aspiracją treści żołądkowej (która może być przyczyną zachłystowego zapalenia płuc). 


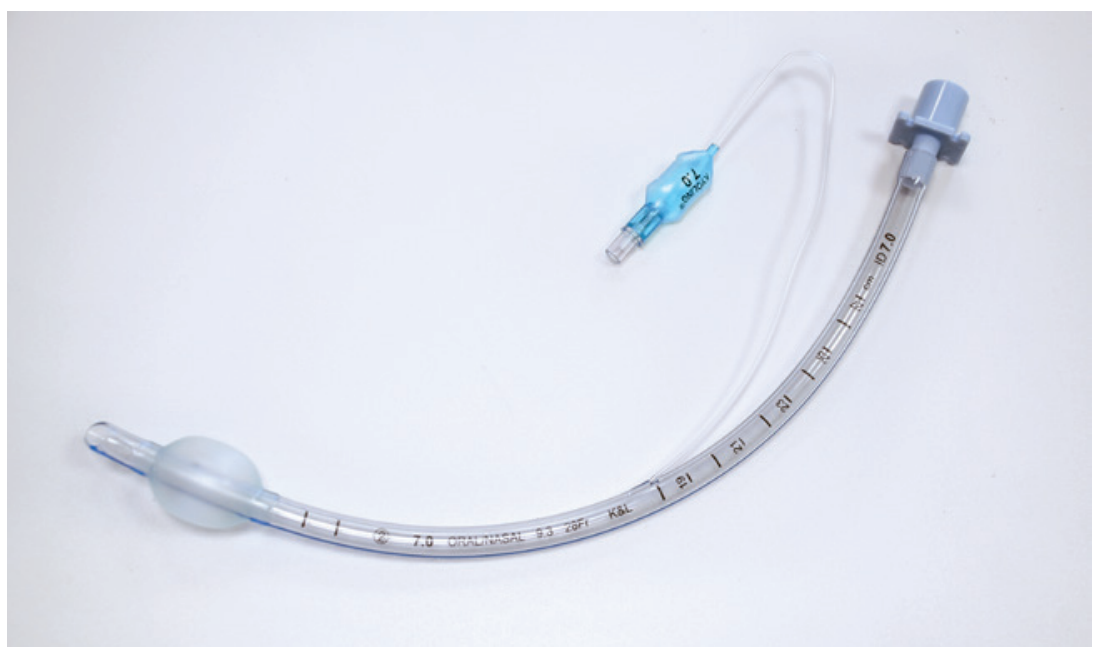

Rycina 8. Rurka intubacyjna

Figure 8. Intubation tube

Źródło: Opracowanie własne.

Source: Own elaboration.

W zespołach ratownictwa medycznego typu podstawowego, jak również w podmiotach współdziałających z systemem, procedura intubacji zgodnie z ustawą o PRM może być przeprowadzana tylko w przypadku zatrzymania krążenia. Do wykonania zabiegu niezbędne jest przygotowanie zestawu składającego się z:

1) laryngoskopu z kompletem łyżek;

2) rurek intubacyjnych (rozmiar docelowy oraz rozmiar mniejszy i większy);

3) kleszczyków Magilla;

4) ssaka;

5) prowadnicy;

6) sprzętu chroniącego oczy i błony śluzowe ratownika medycznego/osoby wykonującej intubację;

7) stetoskopu;

8) rurki UG;

9) mocowania rurki (np. bandaż, opaska do mocowania, uchwyt do rurki intubacyjnej).

Do intubacji należy przygotować rurki w trzech rozmiarach. Dla kobiet zazwyczaj dobiera się rurki w rozmiarach od 7,0 do 8,0, natomiast dla mężczyzn od 7,5 do 9,0 [21].

Tak jak w przypadku innych technik zaawansowanych, tak i w przypadku intubacji, pierwszym krokiem po bezprzyrządowym udrożnieniu dróg oddechowych powinna być preoksygenacja pacjenta prowadzona stuprocentowym tlenem przynajmniej przez 15 sekund (nie dotyczy przypadków NZK). W tym samym czasie zadaniem drugiego z ratowników jest kontrola sprawności i szczelności mankietu uszczelniającego w przygotowanej rurce oraz pokrycie jej w części niemającej kontaktu z krtanią żelem lignokainowym. Niezmiernie istotnym, a często pomijanym elementem, jest dbałość o zachowanie jałowości i czystości sprzętu. Jest to zdanie bardzo trudne do osiągnięcia w warunkach przedszpitalnych, głównie na ulicy. Autorzy niejednokrotnie spotykali się z sytuacjami, w których przed wykonaniem procedury przygotowana rurka, prowadni$\mathrm{ca}$, laryngoskop leżały np. na podłodze lub chodniku. Należy w tym miejscu wspomnieć, że takie sytuacje mogą być spowodowane zmniejszeniem obsady zespołów ratownictwa medycznego typu P do dwóch osób. Należy zdawać sobie sprawę z zagrożenia zakażeniem poszkodowanego, które może z kolei utrudnić dalszy proces terapeutyczny. Przystępując do intubacji, zaraz po natlenowaniu, do jamy ustnej poszkodowanego wprowadza się laryngoskop. Specyficzny ruch zagarniający, od prawego kącika ust ku stronie lewej, pozwala odsunąć język i uwidocznić wejście do krtani. Możliwym niebezpieczeństwem jest wyłamanie siekaczy poprzez oparcie laryngoskopu na zębach (podczas wykonywania niedozwolonej techniki dźwigni). Prawidłowa technika polega na uniesieniu lewą ręką łyżki laryngoskopu za jego rękojeść i poruszeniu jej w górę i do przodu. Prawą dłonią należy delikatnie, ale stanowczo, prowadzić rurkę intubacyjną wzdłuż łyżki pomiędzy struny głosowe. U kobiet rurkę intubacyjną wprowadza się na głębokość $21 \mathrm{~cm}$, a u mężczyzn $23 \mathrm{~cm}$. Mankiet uszczelniający powinien "schować się" za strunami głosowymi [21]. Kolejnym krokiem jest wysunięcie laryngoskopu oraz uszczelnienie mankietu rurki poprzez wypełnienie go powietrzem zgodnie z zaleceniem producenta (tyle, aby uzyskać szczelność) [21]. Kontrolę położenia rurki podczas prowadzenia wentylacji realizuje się poprzez osłuchanie w pierwszej kolejności nadbrzusza, a następnie okolic podobojczykowych oraz środkowo-pachowych [21]. Przy osłuchiwaniu klatki piersiowej szmer oddechowy powinien być słyszalny i symetryczny po obu stronach. Brak szmeru po jednej stronie (zazwyczaj po lewej) powinien wzbudzić podejrzenia, że rurka znajduje się za głęboko i doszło do intubacji oskrzela prawego (wynika to z budowy anatomicznej układu oddechowego - oskrzele prawe stanowi „przedłużenie" tchawicy). W takim przypadku należy opróżnić mankiet uszczelniający, wysunąć rurkę intubacyjną na ok. $1 \div 2 \mathrm{~cm}$ [21], ponownie ją uszczelnić i jeszcze raz osłuchać klatkę piersiową. Narzędziem pomocnym w identyfikacji prawidłowego wprowadzenia rurki intubacyjnej jest kapnometr. Prawidłowa wartość $\mathrm{EtCO}_{2}$ zawiera się w przedziale $35 \div 45 \mathrm{mmHg}$, jednak 
w warunkach prowadzenia resuscytacji krążeniowo-oddechowej wartości na poziomie $17 \div 20 \mathrm{mmHg}$ są zadowalające. Jest to niezmiernie istotny element całej procedury, gdyż nierozpoznanie intubacji przełyku pogłębia hipoksję, powoduje rozdęcie żołądka oraz regurgitację. O intubacji przełyku świadczy powiększenie objętości brzucha, bulgotanie w żołądku podczas jego osłuchiwania oraz pojawienie się treści żołądkowej w rurce intubacyjnej. Ostatnim elementem jest dokładne umocowanie rurki, uniemożliwiające jej przypadkowe wysunięcie. Szybkie i poprawne wykonanie intubacji dotchawiczej wymaga od wykonującego doświadczenia i dużej sprawności. Należy zwrócić uwagę na konieczność ciągłego doskonalenia wykonywania ww. zabiegu. W przypadku trudności w zaintubowaniu poszkodowanego należy rozważyć zastosowanie innej metody, np. maski krtaniowej.

W celu ułatwienia intubacji asystujący może wykonać tzw. manewr Sellicka. Polega on na uciskaniu chrząstki pierścieniowatej. Manewr ten zapobiega ulewaniu się treści żołądkowej oraz pomaga w uwidocznieniu nagłośni. Ucisk zwalnia się po zaintubowaniu poszkodowanego i wypełnieniu mankietu uszczelniającego [21]. Jeśli podczas wykonywania manewru Sellicka wystąpią wymioty, należy zaprzestać uciskania chrząstki pierścieniowatej. Nagły wzrost ciśnienia spowodowany wymiotami i uciskiem może bowiem doprowadzić do pęknięcia przełyku i przedostania się treści żołądkowej do śródpiersia. Należy pamiętać, aby podczas intubacji mieć przygotowany gotowy do działania sprzęt do odsysania [21].

\section{Konikopunkcja}

Konikopunkcja to technika chirurgiczna udrożniania dróg oddechowych wykonywana w przypadku braku możliwości wprowadzenia u pacjenta rurki intubacyjnej lub zastosowania metod nadkrtaniowych. Polega ona na wprowadzeniu przez błonę pierścienno-tarczową w światło dróg oddechowych gotowego zestawu bądź możliwie grubej igły lub wenflonu (np. pomarańczowego o rozmiarze 14G).

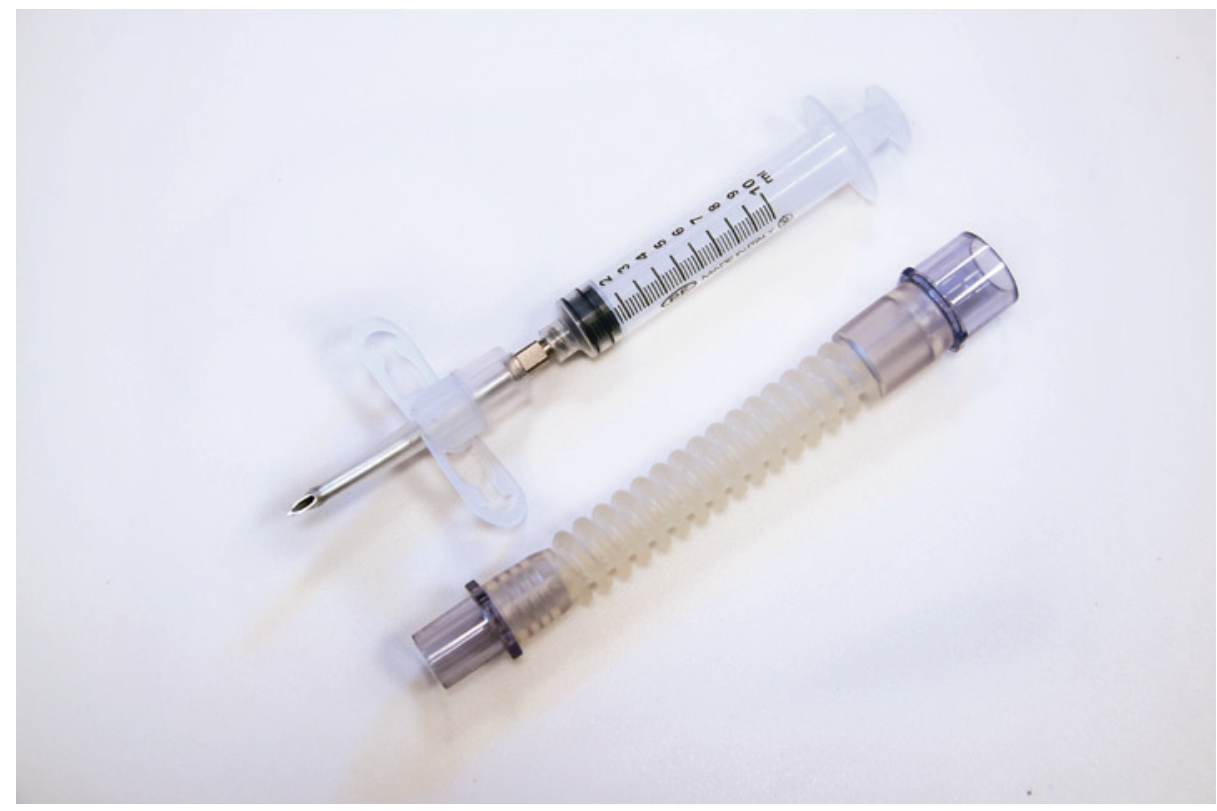

Rycina 9. Zestaw do konikopunkcji QUICKTRACH

Figure 9. QUICKTRACH cricothyrotomy kit

Źródło: Opracowanie własne.

Source: Own elaboration.

Wykonanie konikopunkcji należy rozpocząć od określenia miejsca nakłucia. Znajduje się ono pomiędzy chrząstkami krtani (pierścieniowatą i tarczowatą). W przypadku obrzęku spowodowanego alergią lub urazem może się to okazać bardzo trudne. Następnie należy połączyć igłę/zestaw ze strzykawką, w której znajduje się 1-2 cm soli fizjologicznej lub wody do wstrzyknięć. Przy aspiracji należy wprowadzić kaniulę, nakłuwając błonę pierścienno-tarczową w kierunku klatki piersiowej. Wprowadzenie zestawu do światła krtani spowoduje pojawienie się pęcherzyków powietrza w strzykawce. Procedurę należy wykonać przy ograniczonej sile nacisku, gdyż istnieje ryzyko wprowadzenia igły zbyt głęboko, uszkadzając dolną część dróg oddechowych, a nawet doprowadzając do perforacji przełyku. Podłączenie do zestawu worka samorozprężalnego pozwoli na prowadzenie skutecznej wentylacji. Podłączenie można wykonać za pomocą zunifıkowanej końcówki - w przypadku gotowego zestawu - lub prowizorycznego łącznika ze strzykawki bez tłoka i końcówki rurki intubacyjnej. Podobnie jak w przypadku intubacji, konieczne jest efektywne unieruchomienie i stabilizacja wprowadzonej igły. Z uwagi na jej niewielkie światło i długość istnieje duże ryzyko jej przypadkowego usunięcia. Jest to zabieg niezmiernie stresujący, wykonywany sporadycznie, stąd wskazane jest przeprowadzanie okresowych szkoleń przypominających i doskonalących umiejętności w tym zakresie. 


\section{Podsumowanie}

Nowelizacja ustawy o Państwowym Ratownictwie Medycznym znacznie rozszerza zakres wykonywanych czynności przez ratowników medycznych, którzy pracują w PSP lub OSP. Do tej pory prowadzili oni działania ratunkowe tylko na poziomie kwalifikowanej pierwszej pomocy, a po wprowadzeniu zmian mogą wykonywać medyczne czynności ratunkowe (MCR), w tym m.in. przyrządowe udrożnianie dróg oddechowych. Dzięki rozszerzeniu zakresu działań ratowników medycznych w PSP lub OSP istnieje szansa poprawy jakości prowadzonych działań ratunkowych. Czas podjęcia pierwszych działań ratunkowych ma bardzo duże znaczenie dla poszkodowanych. Bardzo często zdarza się, że to właśnie strażacy przybywają pierwsi na miejsce zdarzenia. W celu udoskonalenia jakości prowadzonych przez nich działań należałoby odpowiednio przygotować sprzęt, jakim dysponują PSP i OSP.

\section{Wnioski}

1. Mimo szybkiego postępu metod alternatywnych intubacja dotchawicza nadal jest najbardziej bezpieczną metodą udrożniania dróg oddechowych.

2. Techniki nadkrtaniowe gwarantują w większości przypadków skuteczną i szybką metodę udrożniania dróg oddechowych.

3. Szybkość zastosowania technik alternatywnych znacznie przewyższa intubację; nie oznacza to jednak, że techniki te stanowią najskuteczniejszą metodę wentylacji.

4. Szeroki wachlarz urządzeń pozwala ratownikom medycznym wybrać najlepszą metodę w zależności od umiejętności.

5. Nierozpoznana niedrożność dróg oddechowych nasila hipoksję, która jest potencjalnie odwracalną przyczyną zatrzymania krążenia.

6. Systematyczne ćwiczenia pozwalają doskonalić umiejętności z zakresu udrożniania dróg oddechowych.

7. Należy kłaść szczególny nacisk na szkolenia pozwalające ratownikom medycznym w PSP i OSP poznawać nowe techniki udrożniania dróg oddechowych; będzie to skutkować wyższą jakością niesionej pomocy.

\section{Literatura}

[1] Ustawa z dnia 8 września 2006 r. o Państwowym Ratownictwie Medycznym (Dz.U. Nr 191, poz. 1410, z późn. zm.).

[2] Ustawa z dnia 25 września 2015 r. o zmianie ustawy o Państwowym Ratownictwie Medycznym, ustawy o działalności leczniczej oraz ustawy o zmianie ustawy o działalności leczniczej oraz niektórych innych ustaw (Dz.U. 2015, poz. 1887, z późn. zm.).

[3] Rozporządzenie Ministra Zdrowia z dnia 20 kwietnia 2016 r. w sprawie medycznych czynności ratunkowych i świadczeń zdrowotnych innych niż medyczne czynności ratunkowe, które mogą być udzielane przez ratownika medycznego (Dz.U. 2016, poz. 587).

[4] Andres J., Pierwsza pomoc i resuscytacja krążeniowo-oddechowa, Polska Rada Resuscytacji, Kraków 2011.

[5] Campbel E.J., International Trauma Life Support. Ratownictwo przedszpitalne w urazach, Medycyna Praktyczna, Kraków 2008.

[6] Gołąb B., Traczyk W.Z., Anatomia i fizjologia człowieka, Ośrodek Doradztwa i Szkolenia Jaktorów, Warszawa 1981.

[7] Goniewicz M., Rzońca P., Sieniawski D., Rybakowski M., Witt M., Goniewicz K., Udrożnianie górnych dróg oddechowych w stanach zagrożenia życia u dzieci, „Pediatr Med Rodz” 2012, 8(4).

[8] Jakubaszko J., Ratunkowe leczenie urazów, Wrocław 2004.

[9] Kulpok-Bagiński T. Van der Coghen M., Placek B., Stosowanie tlenoterapii w ratownictwie medycznym, "Na Ratunek” 2014.

[10] Machała W., Markiewicz A., Rasmus A., Współczesna koncepcja organizacji systemu opieki w obrażeniach, „Medycyna Intensywna i Ratunkowa" 2002 ,5(2).

[11] Osiński P., Maska krtaniowa, rurka krtaniowa, „Przegląd Pożarniczy" 2014, 9.

[12] Pietrzyk J.J., Szajewska H., Markowicz J., ABC zabiegów w pediatrii. Podręcznik dla studentów medycyny, pielęgniarek i lekarzy, Medycyna Praktyczna, Kraków 2010.

[13] Pietrzyk M., Grześkiewicz M., Gaszyński W., Gaszyński T., Porównanie urządzeń nadkrtaniowych do udrażniania dróg oddechowych pod względem zabezpieczenia przed zachłyśnięciem treścią żałądkową - badanie manekinowe, "Anestologia i Ratownictwo" 2011, 5.

[14] Skrzos K., Alternatywne sposoby udrażniania dróg oddechowych, „Na Ratunek" 2014, 1.

[15] Skrzos K., Drogi oddechowe - cz. I. Anatomia dróg oddechowych. Aspekty prawne, „Na Ratunek" 2013, 6.

[16] Sokołowska-Pituchowa J., Anatomia człowieka, Warszawa 1988.

[17] Szarpak Ł., Kurowski A., Porównanie intubacji laryngoskopem Macintosh I i urządzeniem Cobra PLA wśród ratowników medycznych podczas resuscytacji - badania randomizowane, „Na Ratunek”, 6, 2014.

[18] Szarpak Ł., Madziała M., Czyżewski Ł., Kurwoski A., Ocena efektywności intubacji "na ślepo" z wykorzystaniem urządzeń Cobra PLA i SALT podczas resuscytacji pacjenta urazowego wykonywana przez strażaków-ratowników. Badanie randomizowane krzyżowe z wykorzystaniem manekina, "Ostry Dyżur” 2014, 7(4).

[19] Szarpak Ł., Madziała M., Kurowski A., Zabezpieczenie drożności dróg oddechowych, „Przegląd Pożarniczy” 2014, 2.

[20] Szreter T., Zaawansowane metody utrzymywania drożności dróg oddechowych, "Medycyna Praktyczna. Pediatria” 1999, 4.

[21] Gucwa J., Madej T., Ostrowski M., Zaawansowane zabiegi resuscytacyjne i wybrane stany nagłe, Wyd. Medycyna Praktyczna, Kraków 2017, 51-53.

[22] Instrukcja użytkowania - LMA Classic, http://Imana.com/viewifu. php?ifu=154\&PHPSESSID=c495447a2e167fd91cdbb8b3beaecb87, [dostęp: 22.01.2016].

[23] Instrukcja użytkowania - LMA ProSeal ${ }^{T M}$, http://www.Imana.com/ viewifu.php?ifu=96, [dostęp: 22.01.2016].

[24] Instrukcja użytkowania - LMA Supreme ${ }^{\mathrm{TM}}$, http://Imana.com/viewifu. php?ifu=31\&PHPSESSID=c495447a2e167fd91cdbb8b3beae cb87, [dostęp: 22.01.2016].

[25] Materiał dystrybutora, http://www.paramedica.pl/zalaczniki/LTS \%20i\%20LT\%2006\%2013\%20wer.\%2001.pdf, [dostęp: 22.01.2016]. 
MGR KAMIL KRZYŻANOWSKI - ratownik medyczny, asystent w Katedrze i Klinice Medycyny Ratunkowej, Pracowni Ratownictwa Medycznego, Wydziału Nauk o Zdrowiu z Oddziałem Pielęgniarstwa i Instytutem Medycyny Morskiej i Tropikalnej Gdańskiego Uniwersytetu Medycznego.

DR N. O ZDR. DANIEL ŚLĘZAK - ratownik medyczny, asystent w Katedrze i Klinice Medycyny Ratunkowej, kierownik Pracowni Ratownictwa Medycznego, Wydziału Nauk o Zdrowiu z Oddziałem Pielęgniarstwa i Instytutem Medycyny Morskiej i Tropikalnej Gdańskiego Uniwersytetu Medycznego.

PODINSP. DR PAWEŁ JASTRZĘBSKI - ratownik medyczny, kierownik Zakładu Podstaw Bezpieczeństwa Instytutu Bezpieczeństwa i Porządku Publicznego Wydziału Bezpieczeństwa Wewnętrznego Wyższej Szkoły Policji w Szczytnie.
MGR PRZEMYSŁAW ŻURATYŃSKI - ratownik medyczny i pielęgniarz w Samodzielnym Publicznym Wielospecjalistycznym Zakładzie Opieki Zdrowotnej Ministerstwa Spraw Wewnętrznych i Administracji w Bydgoszczy; asystent w Katedrze i Klinice Medycyny Ratunkowej, Wydziału Nauk o Zdrowiu z Oddziałem Pielęgniarstwa i Instytutem Medycyny Morskiej i Tropikalnej Gdańskiego Uniwersytetu Medycznego.

PAULINA BUCA - ratownik medyczny, dyspozytor w Centrum Powiadamiania Ratunkowego w Gdańsku; studentka Wydziału Nauk o Zdrowiu z Oddziałem Pielęgniarstwa i Instytutem Medycyny Morskiej i Tropikalnej, Gdański Uniwersytet Medyczny.

INŻ. BARTŁOMIEJ ŚLĘCZKOWSKI - student ratownictwa medycznego Uczelni Warszawskiej im. Marii Skłodowskiej-Curie; absolwent studiów pierwszego stopnia na Wydziale Inżynierii Bezpieczeństwa Pożarowego Szkoły Głównej Służby Pożarniczej; specjalista w Zespole Laboratoriów Urządzeń i Środków Gaśniczych CNBOP-PIB. 